Meta

Journal des tradlucteurs

Translators' Journal

\title{
Some Aspects of the Translation of Poetry
}

\section{Ewald Osers}

Volume 23, numéro 1, mars 1978

La traduction poétique

URI : https://id.erudit.org/iderudit/003770ar

DOI : https://doi.org/10.7202/003770ar

Aller au sommaire du numéro

\section{Éditeur(s)}

Les Presses de l'Université de Montréal

\section{ISSN}

0026-0452 (imprimé)

1492-1421 (numérique)

Découvrir la revue

Citer cet article

Osers, E. (1978). Some Aspects of the Translation of Poetry. Meta, 23(1), 7-19.

https://doi.org/10.7202/003770ar d'utilisation que vous pouvez consulter en ligne.

https://apropos.erudit.org/fr/usagers/politique-dutilisation/ 


\section{Some Aspects of the Translation of Poetry}

No literary activity has been the subject of more wisecracks than the translation of poetry. The American poet Robert Frost coined the classical definition : "Poetry is what gets lost in translation.

Naturally, as a translator of poetry, I do not accept Robert Frost's pessimistic definition as being universally valid. He probably doesn't himself. But he is so often right that I should like to take his quip for - as it were - the text of my sermon and examine : 1) what makes poetry; and 2) why this poetry is often lost by the translator.

If we accept that a formal metre-and-rhyme framework is no longer the criterion of poetry, and if - as I hope - we also accept that prose chopped up into short lines does not make poetry, we must clearly look for its specific characteristics in the linguistic texture. I believe that the great majority of those interested in poetry would agree that the true criterion of poetry -one that is equally applicable to metre-and-rhyme verse and to unrhymed poetry - is the internal tension, or temperature, or charge of the language.

The concept of "poetical» or "heightened 》 language is frequently encountered - but rarely questioned - in literary criticism. Its nature was first examined by the Russian Formalists and defined by the Prague Linguistic Circle in the twenties and thirties. More particularly, Mukaroovský, with his concepts of norm and norm violation ${ }^{1}$, demonstrated that the patterns of poetical speech must be analyzed within the context of the total linguistic system.

For the working translator, the principle may be formulated as follows : A word, a group of words, or a phrase derives its tension, its charge, its impact on the reader or listener from its "otherness", from the way it differs from ordinary speech, from the novelty of its employment in a particular context, from the surprise it produces. All these concepts - otherness, difference, novelty, surprise - presuppose comparison. Comparison with a norm, with customary usage.

1. Jan Mukařovský : Máchův Máj, Estetická studie, Praha 1928, La phonologie et la poétique, Travaux du Cercle Linguistique de Prague, cited from : Thomas G. Winner : Jan Mukařovský, * The Beginnings of Structural and Semiotic Aesthetics *, in : Sound, Sign, and Meaning : Quinquageneri of the Prague Linguistic Circle, ed. L, Matejka, Ann Arbor, Michigan, Michigan Slavic Contributions 1976. 
It follows, therefore, that no word or turn of phrase can carry that extra charge that makes it poetry unless there is an alternative, unless the poetic text represents a deliberate choice from among possible options. The question : Is there an alternative? is therefore, in my opinion, central to the whole problem of poetry, and of translating poetry. It is the deliberate choice from among available alternatives that gives a word, or a line, its emotional temperature or charge.

Anyone who reads a lot of translated poetry would, I think, agree that the aspect in which translations most often fall down is in the reproduction of that emotional charge. The first thing, therefore, that the translator of poetry must do - and he must do this right through the poem : for each word, for each word group, for each phrase - is ask himself : What alternatives were there ? And how does the form of words chosen by the poet differ from the alternatives he had available?

Let me start with some illustrations from the classical languages.

There is a line in Homer's Odyssey ${ }^{2}$, describing the sudden darkening of the sky and the outbreak of a storm at sea :

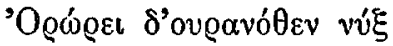

literally «From the sky springs night ». But note the dark vowels, almost the roll of thunder and the crash of lightning.

My Greek is not good enough to examine Homer's alternatives. But Virgil, in the Aeneid, copies the line as :

\section{Ponto nox incubat atra ${ }^{3}$}

It lacks, perhaps, the crash of thunder but it has the same dark vowels and the same ominous note. Some of the readers of this article will, I hope, know enough Latin to realize that Virgil did have a number of alternatives. For "ponto s he could have said «mari»- «mare» in fact is the more common term for the sea - for « incubat » he could have written «incidit», with virtually the same meaning but with two bright instead of dark vowels; for "atra », finally, he could have said « nigra » - again with a high-pitched vowel - though I agree that «nigra », with its suggestion of shining black, would have been less suitable than « atra », dull black.

The point I am trying to make is that any would-be translator of this line into English must realize that Virgil had alternatives for most of the words in his line - not perhaps for "nox» which, happily, has a dark vowel - and that he deliberately chose the dark, menacing-sounding alternatives.

It is obvious, therefore, that a rendering such as

Night strikes from the sky

2. Odyssey, Book V, 294 (and again Book IX, 69).

3. Aeneid, Book 1, 93. 
would be totally, diametrically, opposed to Virgil's evident intention, and that something like

\section{Dark swoops from the clouds}

would be more in line with, at least, the phonetic choices of the poet.

I should next like to illustrate the problem of alternatives by a few examples from T.S. Eliot's Four Quartets. Eliot was very careful about the way he used language : one need only remember his almost programmatic statement in Little Gidding ${ }^{4}$ :

... where every word is at home,

Taking its place to support the others,

The word neither diffident nor ostentatious,

An easy commerce of the old and the new,

The common word exact without vulgarity,

The formal word precise but not pedantic...

What better recipe for any writer?

Now to my illustrations : In East Coker a «memory passage », a flash-back passage, ends with the lines ${ }^{5}$ :

The houses are all gone under the sea,

The dancers are all gone under the hill.

The alternative I am interested in is, of course, « are gone $\$$ in both lines. The overtones of this slightly archaic construction «are gone 》 differ a good deal from the normal modern perfect tense « have gone». \& Are gone » has something more final about it. "Have gone still allows the thought that perhaps they may return one day : « are gone » has a permanent ring about it and, moreover, carries overtones of regret or sadness.

The German translator of the Four Quartets, presumably unaware of the possible alternative in the original text, unfortunately missed this aspect altogether by using «verschwanden ${ }^{6} »$, something that, to my ear, sounds more like a conjuring act than the operation of transience and time - which is what the whole poem is about. reads $^{\text {? }}$

My next illustration is the conclusion of East Coker. The English text

Through the dark cold and the empty desolation,

The wave cry, the wind cry, the vast waters...

Here again the translator should have examined the text for alternatives. He should have noted \& the dark cold 》 - surely the less common way of referring to what, more often, we would call «the cold darkness ». More importantly, he

\footnotetext{
4. T.S. Eliot : Four Quartets, Little Gidding, V. 4-9.

5. Ibid., East Coker, II, 49/50.

6. Alle die Häuser verschwanden unter dem Meer.

Alle die Tänzer verschwanden unter dem Hügel.

Translation by Nora Wydenbruck. T.S. Eliot, Gesammelte Gedichte 1909-1962, Suhr-

kamp Verlag 1972.

7. East Coker, V, 36/37.
} 
should have reflected on «the wave cry, the wind cry». "Cry» is not the usual verb associated with either waves or the wind. In ordinary speech we expect waves to roar or to crash, and the wind to roar or to howl. Unfortunately, the German translation misses the extra charge, the excitement of the unaccustomed use of «cry» and has the entirely conventional, almost cliché, rendering of "Brausen der Wellen, Heulen des Winds ${ }^{8}$ ».

I have no wish to «knock» Nora Wydenbruck's translation of the Four Quartets - there are some very fine passages in it - but a translator's failures often make better illustrations of translation problems than his or her successes.

One final illustration of the importance of spotting the " otherness $\gg$ of poetic language, of the need to realize that it represents a deliberate choice from among several available alternatives. This one is a line near the beginning of Little Gidding. It runs ${ }^{9}$ :

A glare that is blindness in the early afternoon

"A glare that is blindness » would be, in ordinary prose, " a glare that is blinding . But «blinding glare » has become a much-fingered and therefore weakened idiom, and by using the unexpected, novel, startling alternative \& A glare that is blindness \& Eliot restores to the imagine some of the original force of the word : a glare that literally blinds your eyes. To translate the line as if the common word «blinding» stood there would be quite wrong.

We have so far been arguing as if any pair of two languages always offered the same kind of alternative choices. This, of course, is not the case - as I hope to show with my next illustration.

One of Goethe's best-known poems, An den Mond, opens with the lines :

Füllest wieder Busch und Tal still mit Nebelglanz

Note the opening phrase : Füllest wieder Busch und Tal. To my mind a case of sheer genius - the way Goethe jumps in with both feet : no padding, no lead-in, straight into the atmosphere of bushes and valley steeped in moonlight. But why does the opening line grip you by the throat, make you catch your breath? Because it is one of several possible alternatives, and probably the most unexpected one.

Let us look at these alternatives. The normal prose version - which we shall call (1) — would be :

(1) Du füllst wieder Busch und Tal

Other possible, though not very exciting, alternatives would be

(2) Nun füllst du wieder Busch und Tal

or perhaps

(3) Füllst nun wieder Busch und Tal

8. T.S. Eliot, Gesammelte Gedichte 1909-1962, Suhrkamp Verlag 1972.

9. Little Gidding, I, 8. 
Alternatives (2) and (3) relay on a padding word, a Flickwort, " nun 》. Goethe's final choice

(4) Füllst wieder Busch und Tal

owes its poetic power, its charge, to the very fact that it is the least expected of the possible choices.

Now this is not just speculation. We are fortunate enough to have Goethe's draft version of this poem and there the opening line is in fact our alternative (1) :

Du füllst wieder Busch und Tal

We know, therefore, for once with absolute certainty, that the change of this line to its final version, our version (4) :

Füllest wieder Busch und Tal

was a deliberate act of choice.

Let us now consider the position of the would-be English translator. He has, if he is any good, applied the test I mentioned earlier : he knows that Goethe's turn of phrase is the result of a deliberate choice. But what can he do? An inversion of the pronoun-verb order is impossible. The only option he may have is that between the normal modern-English 2nd person singular \& you * and the archaic «thou ». But in terms of surprise, emotional charge or temperature "You fill 》 and « Thou fillst " or even "Thou fillest 》 are really the same thing at different stages in the development of the language. And neither has the tranquil flow, the calm beauty, of « Fïllest».

There is a Rilke poem with a similar attention-catching opening :

Ist ein Schloss. Das vergehende

Wappen über dem Tor

Here «Ist ein Schloss 》 is so much non-prose that it actually strains - some might say : breaks - the rules of the German language. The first thing a would-be translator must do - if he does not give up altogether in the face of the appalling difficulty of the line - is to establish what prose statement the line substitutes for. Obviously it is not just a poetical shortening of « Es ist ein Schloss » - which, in German, would be the answer to the question : What is this? Nor does it stand for « Da ist ein Schloss » or «Dort ist ein Schloss ». "Ist ein Schloss », with the dramatic full stop after the three words, surely means something like "Irgendwo ist ein Schloss», «Es gibt ein Schloss 》, "Es existiert ein Schloss».

Hence the English equivalent, the semantic equivalent, is « There is a castle ». But in terms of power, of mystery if you like, of the suspense created by the three German monosyllables «Ist ein Schloss», the English information-equivalent is, of course, totally inadequate.

But what is the English translator to do with the line? The rules governing the English verb just do not permit a verb-subject sequence in a positive state- 
ment unless preceded by « There». «Is a castle» or even «Stands a castle» just won't do.

I have not been able to find an English translation of this Rilke poem. (It comes from his volume Die frühen Gedichte ${ }^{10}$.) Myself, believing discretion to be the better part of valour, would not attempt to translate it at all. But if I had to translate it, to save my life, my own strategy probably would be to operate without the verb \& Ist 》 and to try to echo the hammer blows of «Ist ein Schloss » by a verb-less word group followed by a full stop, or indeed by the word «Castle» on its own, followed by the full stop.

Ist ein Schloss. Das vergehende

Wappen über dem Tor.

Castle. The family's crumbling

Heraldy over the gate.

Very inadequate, of course. An illustration of the problems which arise when certain syntactic possibilities of the source language are lacking in the target language.

I should now like to touch upon one of the best-known translation problems - a problem stemming from the availability of alternatives in the source language but not in the target language, in our case English. This is the second person singular. Modern English - fortunately, I think - only has « you » for the whole range from the most formal to the most intimate form of address. The only exception, I suppose, is the formalized ceremonial of the Courtroom : "If your Lordship pleases», "If your Honour pleases ». Even in conversation with the Sovereign it is now customary, after an initial «Your Majesty » to switch to plain "Madam» and «you». All other European languages, however, differentiate between a familiar and a «polite » form of address.

In the past English translators, especially of novels, tackled the problem by making characters who, in the original German, are per $D u$, or in the original French qui se tutoient, address each other by Christian names. This was never entirely satisfactory, if only because the patterns of formality in speech behaviour differ considerably from country to country. In Germany and France, for instance, people in the same job - especially middle-class people - may have worked in the same office for years and still call each other Herr Schmidt and Sie or Monsieur Lefèvre and vous - something that would have been inconceivable in England or America even 30 years ago. In France, in particular, the vous address extends further towards the «informal » end of the spectrum than the German Sie, Dutch $U$, or Russian $V y{ }^{11}$. French middle-class children until not so long ago - it is now on the way out - would say vous to each other until well acquainted - something German children would never have done. Admirers of French films will have noticed that lovers, when they get out of bed,

10. Rainer Maria Rilke : Die frühen Gedichte, Insel Verlag 1920, p. 30 (first published under the title : Mir zur Feier).

11. This observation, based on the usage in France, does not necessarily apply to Canada, Belgium or other francophone countries. 
at least after the first time, often still say vous to each other. Again, this would not be thinkable in German, Italian or Russian.

The translator must continually guard against assuming that linguistic structures which look equivalent are in fact equivalent.

The English translator's problem of how to render the $\mathrm{Du} / \mathrm{Sie}, \mathrm{tu} / \mathrm{vous}$, $t u / L e i, t y / V y$ distinction has become a great deal more difficult in our informal age. Not only do television interviewers nowadays address their quarry by their first name, but the practice has become well-nigh universal. At parties I frequently find myself introduced to strangers by first name only - and often, when I go home, I still don't know their last names. Sociologists, for all I know, may hail this as a good thing, but it robs the translator of his traditional device for reflecting the transition from formal to informal address in the texts he translates.

It may be objected that this does not matter very much, and most of the time this would be so. But - to get back to the translation of poetry - let me quote one instance where, to my mind, it matters enormously. And where the absence of the distinction in English is felt, for once, as a disadvantage.

I am thinking of Tatyana's letter to Onegin in Pushkin's Evgeniy Onegin one of the most beautiful passages in the whole of Russian poetry. Many readers will know the situation : Tatyana, an innocent young girl, has fallen in love with Onegin. She is a well-bred girl, of the Russian land-owning class, and she is bowled over by Onegin, the young city fop who has come to the estate as the friend of the fiancé of Tatyana's sister. So she sits down and writes this love letter.

$$
\text { Я к вам пишу ... }
$$

She uses, as of course she would in conversation with the young man, the polite $V y$. And she keeps it up for the next 10 lines or so :

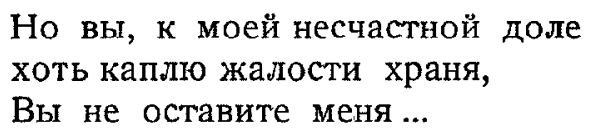

But presently, as lovers will, she gets carried away by her passion and, hardly aware of it, slips into ty :

$$
\begin{aligned}
& \text { Ты в сновидениях мне являлся, } \\
& \text { Незримый, ты мне был уж мил ... }
\end{aligned}
$$

and so on - until, in a kind of post-climactic realization of her appalling breach of etiquette, she decides to let the letter go, trusting to the young man's chivalry, but changes back to a cooler and well-mannered $V y$ as she concludes :

$$
\begin{aligned}
& \text { Но мне порукой ваша честь } \\
& \text { и смело ей себя вверяю. }
\end{aligned}
$$

No one, I think, would claim that this change from the polite to the familiar and back to the polite form of address is unimportant. I think it is enormously important : it registers the whole psychological temperature of the letter passage ; 
it is a great crescendo followed by a decrescendo; it represents what in music one would call the dynamic notation of the passage ${ }^{12}$.

And there is nothing that the English translator can do about it. Here is a linguistic register the English language lacks.

Well, if he can't do anything about it, should the translator worry about it ? Yes, he should worry about it. I mean : he should be aware of it. He must not think that, since both Russian forms of address translate as you, he has provided an adequate translation. He must try to discover - though obviously he would have to be a very great translator to bring it off - he must try to discover if he can conceivably convey the higher temperature of the passage where Tatyana uses the intimate ty by the choice of «warmer » or even more ecstatic words, at least in all those instances where he has a choice between otherwise equaliy suitable alternatives. Since the passage is also enormously dense and closely packed with «message» he will not have much room for manœuvre.

Similar problems can be posed by gender. Roman Jakobson points out somewhere - and I am indebted for this reference to a paper by Professor Thomas G. Winner ${ }^{13}$ - that Lermontov's Russian translation of Heine's poem Der Fichtenbaum und die Palme loses something of the underlying erotic element that is present in the German due to the fact that the two trees have different grammatical gender : one is masculine while the other is feminine. In Russian they are both feminine. Lermontov, at least, had the option of departing from lexical accuracy in order to find a tree that was masculine in Russian. There are such trees. But the English translator, in the absence of grammatical gender, has no choice at all, and no way of reproducing the faint erotic undertones of Heine's text.

Let us go back again to the criterion of heightened tension, emotional charge or temperature that we associate with the language of poetry. We have seen that this derives from a choice of words or word groupings which, by comparison and contrast with the more «usual» alternatives, produce this effect on the reader or listener. In terms of linguistic analysis this statement could be rephrased as : Poetic language is marked by a higher incidence of metaphor than the language of prose.

What is metaphor? Aristotle's definition that it is «the name of one thing applied to another $\gg$ is good enough for our purpose. Metaphor is the extension of the meaning of a word or phrase to another word or phrase. It is the principal source of the rejuvenation of language, and - to my mind at least - a measure of a language's vitality. When we speak of « running a business», " running for the Presidency», "lending a hand», « casting an eye», «turning a blind eye $\gg$ - we all use metaphor.

12. All that V. Nabokov, in his celebrated commentary on Evgeniy Onegin, has to say on this passage is that the switch between formal and intimate form of address is found in the French epistolary novel of Pushkin's day!

13. Thomas G. Winner : Estetika i Poetika Praškog Lingvističkog Kruga », in : Umjetnost Riječi, XVI 2-3, Zagreb 1972, p. 146. 
Like all living things, metaphor gets stale with use, loses its original impact, and becomes an ordinary idiom or even cliché. Some linguisticians, in fact like M. B. Dagut ${ }^{14}$ - want to reserve the term «metaphor " for its first use only, for its creative, inventive application, and argue that by the time it is lexicalized it has ceased to be a metaphor. As a practitioner I would make the point that the concepts of "metaphor» and «lexicalized idiom» are no more than abstractions, marking the starting point and the finish of a linguistic process. It is the area between these two concepts that the translator of poetry is normally concerned with, that gradual spectrum between first use and spent force, the area when a word, a group of words, or a phrase, is no longer a mint coining but not yet a fully accepted and therefore effortlessly comprehended idiom. A group of words still invested with enough of that quality of novelty, unusualness, to produce excitement, tension, an awareness that this is not just ordinary prose, though perhaps no longer producing quite the startling effect of its first use.

This, of course - since it has to do with the process of ageing - is more often a problem in diachronic translation, i.e. the translation of old texts, than in the translation of contemporary poetry.

Once again it is easy enough to formulate the problem - "How new, how original, how startling, was a particular phrase when Shakespeare, or Chaucer, used it?» - and quite difficult to answer it. My own personal belief is that you can't solve the problem in any scholarly sense. Of course, there are reference books which can tell you just when the phrase «a white lie» is first attested - in other words : first used by an author whose writings have come down to us. But this does not tell us anything about the possible currency of the phrase in popular speech - especially as popular speech is one of the main creators of metaphor and linguistic innovation. In other words, we cannot reliably establish what really matters : the impact which the phrase had on contemporary readers or listeners who may, or may not, have been quite familiar with it.

The problem of translating across time is nearly always associated with that of translating across cultures. Let me quote a famous example : Homer's 《 wine-dark sea ».

Anyone who has seen Retzina, the dark-red traditional Greek wine with resin in it, will recognize the attribute. But what about translation into languages whose speakers will be puzzled by the suggestion that the sea has the colour of wine; the kind of wine they know? Is the translator to settle simply for « dark», or perhaps a simile of his own making, like "plum-dark»? I think not. Any really effective substitution would have to involve a liquid, or better still a beverage, that is familiar to the reader but which he himself has never equated with the appearance of the sea.

But the modern translator is again only guessing. What, ideally, he would want to know is the impact of Homer's «wine-dark » on a Greek of his own time. Was it widely accepted that the Greek sea often had the colour of Greek

14. M.B. Dagut : . Can \& Metaphor * Be Translated ? \& in : Babel, International Journal of Translation, Vol. XXII No. 1/1976, Frankfurt/Main. 
wine - in the way, for instance, in which we might accept that some children have « forget-me-not-blue eyes »? Would a pre-classical Greek have gone to his local wine store to ask for an amphora of wine the colour of the sea at evening ? We don't know. But my guess would be : No. "Wine-dark sea », I suspect, came to. Homer's contemporaries with that startling shock of novelty and recognition that characterizes the best metaphors. It hasn't been put that way before, but it is so right you wonder why it hasn't been put that way before.

When a metaphor is brand-new, newly coined - when, therefore, it cannot yet have an equivalent in the target language - the translator, obviously, has to coin that equivalent. And, with very few exceptions, he will go for an exact, literal translation. Again, let me illustrate what I mean.

Right at the beginning of Under Milk Wood ${ }^{15}$, Dylan Thomas describes the night in the Welsh village of Llaregib as "Bible-black \& - to my mind one of countless instances of linguistic or poetic wizardry in that radio play. The English reader or listener will be familiar with the idioms « coal-black 》, "pitchblack », « jet-black» - but «Bible-black» at once captures his imagination. Obviously, "Bible-black» is not a new or a different colour : what the new metaphor does is illustrate the same colour, the same blackness, in a new way : the black of the familiar Bible binding. Familiar - and this is where Dylan Thomas's genius comes in - not only to his readers or listeners but much more so to the Chapel-going, sin-and-guilt-ridden people of Llaregib, the characters in his poetic radio play. By describing the night as «Bible-black $\gg$ he provides a key clue to the whole atmosphere.

Erich Fried, probably the best translator of English poetry into German, has therefore, quite rightly, rendered «Bible-black » by a literal «Bibel-schwarz » - even at the cost of the alliteration ${ }^{18}$.

Once a metaphor gets accepted and weakened, the need for literal translation becomes less pressing. "Coal-black» or « pitch-black \$ have lost much of their original force and, to my ear, mean little more than deep black. « Jetblack », again to my ear - and this is bound to be subjective - retains a little more of the force of the metaphor, but not so much that I would object (if applied to a girl's eyes) to seeing it rendered in German as «kohlschwarz 》 or (if applied to a girl's hair) as « rabenschwarz ».

There is, of course, no guarantee that a literal rendering of a metaphor that is brand-new in the source language will be equally brand-new in the target language. For all we know, there may be a language somewhere in which the equivalent of «Bible-black » is as common as «pitch-black» is in English.

Sometimes, of course, the use of culture-linked metaphors can lead to obscurity in translation. Let me quote an example from my own experience. Rose Ausländer, a German poet, has a poem whose first verse, in my translation,

15. Line 3 .

16. Dylan Thomas : Unter dem Milchwald, ein Hörspiel für Stimmen, Deutsche Nachdichtung von Erich Fried, Drei Brücken Verlag, Heidelberg, 1954. 
runs as follows ${ }^{17}$. Or rather : I shall stop short of the translation problem and leave the difficult words in the original :

\author{
Weeping willows \\ melancholics \\ with drooping shoulders \\ swaying wie Betende
}

In fact, we have here an illustration of more than one translation problem. Problem No. 1 is : The German substantival present participle has no gender distinction - but, since English lacks this construction except for certain verbs with a Latin root, the translator must decide whether these swaying people at prayer are masculine, feminine, or of unspecified sex.

Problem No. 2 is : What does it mean altogether? It would be interesting to discover how many readers of this article understand the simile. In Rose Ausländer's native Czernowitz in the Bukowina, with - before the war - a large Jewish community, it would have been instantly understood. Jewish men sway in prayer - and, as far as I am aware, only Jewish men. Christians kneel or stand with heads bowed, Moslems prostrate themselves. And Jewish women do not sway. Only the men do.

That, at least, settles the first question. The translation must be «like men at prayer » and not, for instance, "like people at prayer ».

But should the translator go further, in terms of interpretation? Should one say "like Jews at prayer», or "like men in a synagogue», or something of that kind?

«Swaying like men at prayer » would, I think, be meaningful to educated readers - and, of course, also to non-Jews since we all know a little about each other's cultural and religious traditions - in London, Manchester, New York and Melbourne. But what about Delhi, in the numerically largest country with English still one of the official languages? Indians are motionless in prayer. Or what about the American Bible belt ?

But if one takes another look at the German original one realizes that it faces the same problem within its linguistic sphere. The number of Jews and certainly Jews given to orthodox observance and customs - in postwar Germany and Austria is so small that the phrase, even among Rose Ausländer's German readership, must hover on the edge between comprehension and bemused guessing.

I may as well admit that I decided, quite simply, on :

Swaying like men at prayer.

Some of my early illustrations in this article came from T.S. Eliot, and my final one comes from him too. It is another cross-cultural problem.

A poem written by Eliot in 1920, and entitled A Cooking Egg, ends with the lines ${ }^{18}$ :

17. Blind Gestures, from Selected Poems, Rose Ausländer. Translated from the German by Ewald Osers, London Magazine Editions 1977, p. 59.

18. T.S. Eliot : Poems 1920, A Cooking Egg, p. 31-33. 
Over buttered scones and crumpets

Weeping, weeping multitudes

Droop in a hundred A.B.C.'s

Eliot; an American by birth, had by then become very much an Englishman. On a lecture tour in the spring of 1977 I tried these three lines on audiences at 10 United States universities, to discover if they could make any sense of them. Roughly half the audience in each place knew what "scones》 were; between one-third and a half knew what «crumpets » were. But no one, with the exception of two English people, understood the reference to the A.B.C.'s. Yet to the English reader an «A.B.C.» is as instantly comprehensible as a «Howard Johnson» would be to an American or Canadian. It was a chain of restaurants or tea rooms, inexpensive but with an air of refinement : one sat at little tables, not at the bar.

If these English lines are obscure even to readers using another version of the English language, what is the translator into another language to do with them? How should he render this specifically English institution - specifically English, that is, for afternoon tea with buttered scones and crumpets? Let us see what the German translator has done ${ }^{19}$. In German the lines read :

Weinend, weinend in hellen Scharen

Sitzt das gebeugt vor Huhn, Pommefrits und Pils -

Die Menschmillionen in ein hundert Hühnergrills

Literally translated : Weeping, weeping multitudes / sitting bent over chicken, french fried, and lager /in a hundred chicken grills. The translator, Eva Hesse, is usually a very good translator but here, I think, she has gone totally wrong. By turning the tea place into a chicken grill she misses - in my view - Eliot's point.

Buttered scones and crumpets in an A.B.C. are very different from a meal in a chicken grill : they are, or were in Eliot's day, something between meals, an almost ritualized pause between finishing one's working day and commuting home. The «weeping, weeping multitudes» are the office workers and shop workers who have just put another day behind them and who, during their unwinding ritual of tea and crumpets, are suddenly overcome by the dreariness, the drabness, the frustration and the emptiness of their lives. Eliot's vision, to my mind, is very different from the purposeful eaters in a Kentucky Chicken place. So different that one wonders what the German reader can make of all those tears shed over chicken, french fried and lager.

I do not want to be misunderstood. Eliot's « A.B.C.'s » obviously had to be represented by some other institution, one familiar to the reader. My complaint is not that the translator has transposed the scene into a different setting but that she has transposed it into a wrong setting, one with the wrong atmosphere and associations. The keynote of Eliot's passage is not the food intake but the brief stop, the moment of «neutral » between « office gear» and « domestic

19. T.S. Eliot : Gesammelte Gedichte 1909-1962, Suhrkamp Verlag 1972, p. 63. Ein UnFrischei, translated by Eva Hesse. 
gear », the vulnerable in-between moment. There may be no exact cultural equivalent - indeed the whole custom of « unwinding 》 may be peculiar to «commuting societies» - but I should have thought that the cocktail lounge in the U.S.A., the pavement café in France, and the Kaffeehaus or Konditorei in Germany and Austria would be much closer equivalents in terms of atmosphere and psychological function.

A warning in conclusion. The translation of poetry, as every practitioner knows, is beset by dozens of problems, pitfalls, hurdles and obstacles. Some of these are generic, in the sense that they recur in some form or other, while others are specific to a particular text. Of the generic ones I have, in this article, discussed only two : (1) alternatives, (2) metaphor. But I have no doubt that these two are responsible for more translation failures than all other difficulties combined.

I believe that the nature of the translation problems can be analyzed and defined, and that a general strategy for tackling them - or, at least, the generic ones - can be mapped out. But I do not believe that anything like a detailed tactic, blueprint or drill - one that would be applicable to all situations - can ever be developed. Within a broad general strategy specific solutions must always remain intuitive.

EWALD OSERS 